\title{
The Migrant Other: Exclusion without Nationalism?
}

\author{
Caress Schenk ${ }^{*}$ (i) \\ Nazarbayev University, Nur-Sultan, Kazakhstan; Tomsk State University, Laboratory for Social and Anthropological Research, \\ Tomsk, Russia \\ *Corresponding author. Email: cschenk@nu.edu.kz
}

\begin{abstract}
Migrants are an easy, visible Other, seeming to fall neatly into the us-versus-them framework of nationalism. Nevertheless, much of the scholarly approach to migrant identity, with the partial exception of a largely separate literature on citizenship, has eschewed overt ties to nationalism studies. When us-versus-them language is used in relation to nationalism, the focus or nodal point is the identity of the seemingly homogenous "us" of the nation. However, when migrants are othered, the focus is not always the nation, and while othering migrants always creates exclusion, it is not always exclusion from a nation or identity group. This state of the field article analyzes the literature on populism, securitization, biopolitics, and other critical scholarship related to the issue of othering migrants. In each of these bodies of work, different sets of "us" are set against migrants, some of which evoke identity and others of which do not, elucidating the links (or the lack thereof) of each approach to the study of nationalism. In each of these frameworks, the migrant Other comes up against a different frame of reference, leaving migrants themselves (or any sense of migrant identity) somewhat lost amid the analytical frameworks, at continual risk of being re-othered as victims of circumstance without agency.
\end{abstract}

Keywords: migration; populism; securitization; biopolitics

The literature on migration takes many diverse paths to incorporating identity into its analysis, though studies of migration and nationalism have not often converged in a theoretically synergistic way. It is curious that the migrants that have become an almost singular object of political scorn, resulting in immigrant bans and refugee blockades, have such a fraught relationship with the national identity to which politicians seem to be appealing. Migrants are an easy, visible Other, seeming to fall neatly into the us-versus-them framework of nationalism. Nevertheless, much of the scholarly approach to migrant identity, with the partial exception of a largely separate literature on citizenship, has eschewed overt ties to nationalism studies. Why is this the case?

This state of the field analysis surveys both analytical and normative scholarships to suggest that creating the migrant Other, through political, legal, or discursive practices, does not always contribute to an understanding of national identity. When us-versus-them language is used in relation to nationalism, the focus or nodal point is the identity of the seemingly homogenous "us" of the nation (De Cleen and Stavrakakis 2017). However, when migrants are othered, the focus is not always nation, which is why we can observe antimigrant or xenophobic rhetoric that is not nationalist (Schenk 2018). In other words, while othering migrants always creates exclusion, it is not always exclusion from a nation or identity group. As such, this article probes the limits of nationalism concepts for the analysis of various types of identity, in this case migrant otherness,

\footnotetext{
(C) The Author(s), 2021. Published by Cambridge University Press on behalf of Association for the Study of Nationalities. This is an Open Access article, distributed under the terms of the Creative Commons Attribution licence (http://creativecommons.org/licenses/by/4.0/), which permits unrestricted re-use, distribution, and reproduction in any medium, provided the original work is properly cited.
} 
with broader applications to studies of structural racism, gender, and efforts to decolonize scholarship that engage us-versus-them categorization and exclusionary power dynamics. In the following pages, I analyze how the literatures on populism, securitization, biopolitics, and other critical scholarship approach the issue of othering migrants, considering both the relevant technologies of governance and the concepts scholars have developed to encapsulate ideas and practices related to how migrants are constructed as Others. These literatures do not represent the full scope of approaches to migrant identity and engage only peripherally with the large migration literature that focuses on migration policymaking, migrants' access to rights, and identities across borders. Mainstream approaches to migration are not concerned with othering, per say, which is pursued more directly in the critical and normative literatures that incorporate discursive practices to a much greater extent than traditional analysis. These four literatures present an opportunity to explore how migrants are constructed as Other through different mechanisms that elucidate by whom, for whom, and through what process migrants are othered. Presented from most mainstream to most critical, each of these bodies of work analyze different sets of "us" that are set against migrants, some of which evoke identity and others of which do not, elucidating the links (or the lack thereof) of each approach to the study of nationalism.

\section{Populism and Party Politics: Democratic Othering}

In the rise of European and US populism since the 2010s, anti-immigrant rhetoric has become a key strategy for mobilizing votes. Since populism as an ideology or technology of governance has become a vehicle for othering migrants through scapegoating rhetoric (Wodak 2015), its analysis seems a promising avenue for reconciling the place of migrants in the nationalism literature. Indeed, identity has become increasingly central to party politics and voting behavior, leading to the rise of support for populist parties (Stroschein 2019). The identity in question in most studies, however, is that of voters. In other words, the "us" under analysis in the populism literature is the people, or a nation-like identity group constructed by the political discourse for the purpose of electoral gains. The Other in this case need not necessarily be homogenous, and therefore even a diverse group like migrants can offer a convenient target for othering. The literature on discourses of populism has shifted focus from the identity of the voters to how migrants are portrayed, yet attention remains on the role of migrants as infiltrators rather than a sense that migrants have any common identity.

The mechanism used by populism to other migrants is electoral rhetoric, which offers the public a choice they innately desire (the demand side of populism) or are easily convinced by (the supply side). This is a democratic othering because it relies on the institutions and processes that enable the choice of the demos. Electoral discourses make their appeals through policy promises and party platforms (Eger and Valdez 2019), campaign visuals (Matthes and Schmuck 2017), and media coverage (Bos and Brants 2014; Wiggen 2012). However, many studies that utilize mainstream social science methods, such as public opinion surveys or large election datasets focus on relationships between predetermined variables and as a result fall short of an explanation for why this othering of migrants is effective for electoral purposes. They do not elaborate the interlinkages between supply-side factors, e.g. opportunity structures or party development (Rydgren 2007; Muis and Immerzeel 2017), and demand-side factors, e.g. triggers for anti-immigrant attitudes including increased migration, economic crisis, or unexpected refugee flows (Kuntz, Davidov, and Semyonov 2017; Billiet, Meuleman, and Witte 2014; Gorodzeisky and Semyonov 2020; Stockemer et al. 2020). It is precisely at this nexus between supply and demand that the relationship between the "us" of the voters and the Other of migrants remains underspecified in traditional approaches to the study of populism.

Discursive approaches to the study of populism offer some clues to how the mechanism of antimigrant rhetoric connects with the public to produce electoral outcomes. Though less specifically focused on migration-related factors, discursive studies of populism elaborate how the creation of scapegoats and symbols evoke fear among the population (Wodak 2015). The mechanisms of othering used in political campaigns and increasingly in social media (Salgado 2019; Sakki 
and Pettersson 2016) are activated through the creation of crisis and the image of enemies responsible for society's ills, which draw more on fear than on fact, and are used to justify policy responses that exclude and eliminate these Others (Wodak and Krzyżanowski 2017; Krzyżanowski and Ledin 2017; Moffitt 2016). Though the language of identity is utilized, populism remains a political technology, even a performance (Moffitt 2015; Stavrakakis et al. 2018), that is focused on the relationship between voters and elites. Ultimately the migration issue is mobilized by populists to highlight the failures of the political establishment (Salgado 2019; De Cleen and Stavrakakis 2017). ${ }^{1}$ In this sense populism can replace the Other of migrants with any number of alternative targets, since it is not the identity of migrants that is important but merely the role they play in the political process.

Discursive analyses of populism begin to uncover why and how electoral politics can effectively produce a democratic Other through scapegoating migrants. However, in the process of shifting focus from the identity of voters to the ways in which migrants are framed, the possibility of the nation serving as a focal point in these discursive approaches dissipates. Instead, the focus is on how migrants and minorities are racialized and demonized, and the links between the identity of the "us" and the identity of the Other remain unexplored. As a result, the literature shifts away from concrete linkages to national identity, a trend that is continued in the approaches discussed in the following sections.

\section{Securitization: Strategic Discursive Othering}

Whereas populism others migrants as enemies of the public good, securitization, as a technology of governance, goes further to present migrants and migration as an existential threat in need of an urgent solution (Buzan and Waever 2003). The focus is on migrants as the bearers of concrete threats, while the nation (including threats that may come from within the nation) lingers as abstract in the background. In fact, neither the identity of society (whether a national idea or a more general concept of a political community) nor the identity of migrants is particularly important for securitization. Rather, as with populism, the othering of migrants centers around their functional role. In securitization, the othering mechanism is strategic, using discourses of threat to justify policy change that may occur by extraordinary means, or outside regular policymaking channels. Two recent developments in the securitization literature demonstrate an expanding focus on who is involved in this strategic othering. First, a shift to analyze how discourses become embedded in everyday practices shows that othering is done not only by top policy makers but is increasingly actualized through the implementation of policy by lower-level state actors. Second, an increased focus on refugees or humanitarian migrants shifts the target of the othering to a specific type of threat (Watson 2009; Hammerstad 2014).

The contributions of the Paris school of securitization studies has moved analysis beyond an original focus on speech acts (rhetoric) to incorporate the everyday routines and practices of state actors that interact with migrants, from military and police to bureaucrats who use an intuitive sense of which migrants are legal or illegal to justify their processes of sorting and selecting people at the borders (Bigo 2014; Bigo and McCluskey 2018). This bottom-up approach shifts from analysis of episodic or exceptional statements by elites to the ways in which elite rhetoric justifies and becomes embodied in everyday practices (Yuval-Davis, Wemyss, and Cassidy 2018).

Other recent contributions to securitization studies have focused on how refugees are framed as a security risk in the context of the 2015 European refugee crisis, an othering that highlights the danger of mobile people and eschews differentiation of migrants with different identities, experiences, and ambitions. These analyses start with the use of emergency measures and securitized discourses central to early definitions of securitization (Ferreira 2018), then show how the language of crisis is not only to justify policy choices but also to flatten distinctions between migrants that might be hardworking, those that seek the social services of European states, and terrorists or criminals. Some findings suggest these securitized frames are additionally cast in gendered and racialized terms (Gray and Franck 2019; Stachowitsch and Sachseder 2019). 
An important insight of recent work is that the securitization strategies used by elites do not always work (Hintjens 2019). They sometimes fail to convince the public because of competing humanitarian framings of refugees. This finding highlights the importance of the audience (i.e., the public) for the success of the strategic othering of securitization. In the case of humanitarian migrants, the public may not accept the othering of securitizing discourses but instead choose an alternative framing. As with the analysis of populism, where establishing the linkages between supply and demand is persistently difficult, the current moment in securitization studies suggests that capturing public perceptions of elite discourse similarly eludes scholars.

Despite recent critique that securitization studies, and international relations more broadly (Zvobgo and Loken 2020), are embedded in racial (Howell and Richter-Montpetit 2020) and colonial (Bertrand 2018) power structures, securitization studies remains a useful departure point for identifying mechanisms of producing migrant otherness through elite discourses beyond populism. Racially and colonially oriented frameworks remain essential for understanding the various ways in which migrants are othered, but they are better addressed in relation to the critical literature of this review's final section, perhaps because of the limitations of securitization studies in these areas. Nevertheless, securitization approaches usefully extend the framework for understanding how elite-driven discourses produce othering of migrants in a way that can be applied outside of Western contexts, as migrant-receiving countries throughout the world have been shown to utilize securitization practices (Arcarazo and Freier 2015; Arifianto 2009; Bashirov 2018). Yet without a mechanism like the electoral politics central to the analysis of populism, state-society linkages in the process of securitization are even more difficult to establish as there is not a ready-made feedback mechanism for assessing popular perceptions of securitization strategies. Assessing the degree to which securitized rhetoric speaks for large swaths of society would be especially problematic in cases where the "us" of society (given that there is no national identity frame in securitization studies) does not speak as a singular voice against the migrant Other. Instead of the seemingly homogenous identity of the nation, migrants are set against an idea of security, once again othered by a role they are cast in rather than an identity they embody.

\section{Biopolitical Approaches: Othering through State Power}

Some scholars of securitization have turned to biopolitical approaches to explain policies that simultaneously other and humanize migrants (Mavelli 2017; Fassin 2011; Davitti 2018), such as the parallel efforts of governments in Europe to militarize borders and expand search and rescue type operations in the Mediterranean (Van Reekum 2016). ${ }^{2}$ The biopolitical state, based on wideranging applications of Michel Foucault's concepts of biopolitics and biopower, is a concept developed in the literature to denote an activist array of agents and institutions of power that holds human lives as the object of political exercise. Biopolitics are the techniques of governing a collective of biosubjects that render otherness by shifting migrants outside of the legal order of the state. As a result, biopolitical approaches take a step further away from identity politics and nationalism studies because the type of belonging that migrants are excluded from is legal, or even from humanity itself, rather than from any particular identity group.

Many biopolitical approaches to migrant othering begin with Giorgio Agamben's (1998) Schmittian concept of sovereignty and the state of exception, which allows a sovereign to suspend the juridical order under certain conditions (Schmitt 2005). ${ }^{3}$ Running through many biopolitical treatments of migration is Agamben's idea of bare life, or a life that is excluded by the sovereign from all social and political community. Estrangement is the central condition for othering, and the primary consequence is the potential for violence and death without legal repercussions. Recent work on bordering, deportability, and detainability explore how traditional concepts of spatially delineated states with legal systems that operate in straightforward ways must be adjusted to understand the ways in which migrants are othered by the biopolitical state's exercise of power. 
Borders in the biopolitical view are not a concept of the Weberian territorial reach of the state but are rather a Foucauldian assertion of the state's reach over the body politic to control and mold the population into a productive entity (Fassin 2011). Biopolitical borders "can happen anywhere" (Van Reekum and Schinkel 2017): they are liquid and nonlinear (Davitti 2018), flexible and itinerant (Casas-Cortes, Cobarrubias and Pickles 2015), and contingent (Walters 2015). They may involve temporary camps and other detention zones in informal spaces or outside the traditional spaces of the state (Davies and Isakjee 2015; Davies, Isakjee, and Dhesi 2017; Rygiel 2011; Deleixhe 2019), creating a zone of indistinction where migrants can be killed or harmed with impunity. For example, increasingly militarized border control makes migrant passage and entry ever more dangerous, exposing migrants to the bare life as they regularly encounter violence and death (Kynsilehto 2017; Gilmartin and Kuusisto-Arponen 2019; Jones and Johnson 2016; Squire 2017; Davitti 2018; Cuttitta and Last 2019; Rygiel 2016). In the biopolitical sense, border control allows the sovereign ultimate control over death through systematic neglect or "violent inaction" by the state (Doty 2011; Davies, Isakjee and Dhesi 2017). ${ }^{4}$

Similarly, traditional notions of deportation denote the movement of migrants across borders, evoking clearly delineated spatial and legal borders that are complicated by biopolitical approaches (Dines, Montagna, and Ruggiero 2015; Rygiel 2016). Deportability is a concept used to elaborate how individual migrants are rendered Other even if they are not discovered or physically removed from a state, simply because there is the possibility that they could be (De Genova 2010). Whereas deportability engages the notion of othering in terms of borders, citizenship, and physical location, the concept of detainability (De Genova 2019) allows for the possibility that the migrant Other may remain physically inside the state even if they are "legally absent," whether or not they are physically confined (Sampson 2019). The concepts of deportability and detainability engage the biopolitical state of exception and the idea of spectacle, which renders migrant illegality visible through performative acts by states (Van Reekum 2016; De Genova 2013, 255; 2015; Dines, Montagna, and Ruggiero 2015; Mainwaring and Silverman 2017; Tazzioli and Walters 2016). These performances convey to the public (through media images) the idea that borders are a concrete reality (Van Reekum and Schinkel 2017), that law has clear boundaries, and that a state's subjects are easily categorized.

While there is an implicit public or society (though not something conceptualized as a nation) as the audience of migrant othering, they remain passive and peripheral. Biopolitical approaches are curiously silent on horizontal relations within society, focusing more on subjectivity vis-à-vis the state. Those that belong to the legal community remain in the background of analysis. Migrants are othered because they fall outside the law, outside the legal community of the state, and are beyond access to justice. Migrants are neither othered in terms of identity, nor because of the role they play in the political process as with populism and securitization. Instead, they are othered because the biopolitical exercise of state power extends its ethic of care for the population in ways that do not cleanly map onto traditional concepts of the rule of law, where legality is rendered in black-andwhite terms. Nevertheless, because of the focus of biopolitical approaches on indeterminacy and expulsion from legal protection, migrants are continually presented as vulnerable and with limited agency. This is a primary issue taken up in the next section, which demonstrates that identifying and labeling injustice may in certain cases reinforce otherness.

\section{Critical Approaches: Structural Discursive Othering}

The critical approaches that make up the final section of this review take us even further afield from concepts of nation and nationalism because migrants are not set against any particular identity group but are rather othered vis-à-vis power holders and power structures. Beyond the exclusion wrought by the state as conceived in biopolitical approaches, these critical studies count academics, policy experts, and international organizations among power holders who further migrant othering. Continuing in a normative vein, critical approaches highlight how discursive structures 
perpetuate the inequality of the migrant Other. ${ }^{5}$ They share an emancipatory tone or goal, either seeking to empower migrants themselves or to recast the ontological and epistemological frames scholars use to understand the migration process. Recent critiques of the labels used for migrants and the application of these insights to the literature on migrant brokerage demonstrate how framing migrants in crudely simplified ways can itself other migrants by reinforcing stereotypes.

A growing scholarship ${ }^{6}$ problematizes the inherent othering that occurs when migrants are given a particular label. Many scholars seek to complicate or nuance dichotomies such as migrant and refugee (Crawley and Skleparis 2018; Sajjad 2018), migrant and expatriate (Kunz 2020), sham and real marriages in the context of family migration (Moret, Andrikopoulos, and Dahinden 2019), legal and illegal (Achilli and Samra 2019), high- and low-skilled workers (Baas 2017), and internal and international migration (Xiang 2016). These dichotomies often set up a normative Other that centers around the idea that migrants lack agency unless they are engaging in dubious behavior. Some argue that simply using the word "migrant" at all others mobile people and reinforces methodological nationalism, or the idea that the current system of states and citizenship is a natural and objective reality (Iosifides 2017). As a corrective, many critical scholars are interested in empowering local (or bottom-up) knowledge, "decolonizing" knowledge production (Mignolo 2011; Bejarano et al. 2019), and "de-migrantizing" the literature (Iosifides 2017; Tudor 2018; Talleraas 2020).

The literature on migration brokerage, or the professional facilitation of mobility by different types of intermediaries, further illustrates the consequences of labeling and demonstrates the need to continually revisit the categories in use. In this case, the normative preference for "legal" or "regular" migrants is a stumbling block for creating categories that accurately reflect migrant experience. Balčaite aptly states that "the prevailing image of a desirable migrant is that of a lawabiding independent individual traveling through the authorized channels after obtaining the required documentation" $(2020,36)$. This image suggests that migrants lose agency if they are ushered through irregular migration channels by brokers, intermediaries, or smugglers. ${ }^{7}$ Thus even in seeking to reenfranchize the illegal migrant Other as a person with rights to safe and legal access to migration, exploited and victimized migrants are re-othered vis-à-vis their free-agent counterparts (Deshingkar 2019).

In many cases, the intermediaries and brokers that facilitate the migration process are cast as unscrupulous, exploitative, and even criminal (Landry 2016), themselves othered, whether they are based in family and social networks (Ma 2018) or organized crime (Baird and Van Liempt 2015). Recent studies show a range of motives among brokers, from profit to altruism to friendship to a type of political activism where intermediaries offer safe passage to refugees outside of laws they deem unjust (Achilli and Abu Samra 2019; Picherit 2019), or what Landry calls "humanitarian smuggling" (2016, 1). Several scholars have shown that informal networks and brokers tend to illicit greater trust than state-facilitated programs (Åkesson and Alpes 2019; Bylander 2019; Deshingkar et al. 2019) because norms of reciprocity and social and cultural embeddedness mark the intermediary sphere (Deshingkar 2019). Intermediaries can offer increased social mobility and status (Alpes 2013; Wee, Goh, and Yeoh 2019; Tuckett 2018), and help migrants appear desirable to employers and receiving states (Kim 2018; Deshingkar 2019).

Critical approaches show how migrants often seek secure passage and improved life conditions more than "legality" (Åkesson and Alpes 2019; Deshingkar et al. 2019) and that engagement with intermediaries may in the end increase the agency of migrants (Deshingkar 2019). Recasting the services brokers offer, including document procurement, travel arrangements, translation, skills trainings, and insider knowledge, as market purchases or investments by migrants (Kim 2018) and focusing on the bottom-up knowledge production arising from migrant experience (Baird and Van Liempt 2015) can therefore help to reenfranchise the victim-migrant Other.

In these critical perspectives, the migrant Other is not set against a nation or identity group of any sort. Instead the Other is set against an ideal of a legal migrant with agency and rights. These ideas of otherness are often politically constructed and top-down (Collyer and De Haas 2012), used 
to simplify and quantify (Moncrieffe 2007), with the consequence of flattening and homogenizing human mobility experiences. Once created, academics and practitioners alike may have difficulty seeing beyond the artificial nature of categories (Bakewell 2008) because they come to be seen as natural, objective, or value-free (Sajjad 2018). Categories become embedded in policy (Dauvergne and Marsden 2014) and are mapped onto different legal, political, and social statuses (Robertson 2019), each evoking different moral imperatives (Smith and Waite 2019) and emotional reactions (Baas 2017). Categorizations can further create a slippery slope of associations, blurring the boundaries between legal status, race, and religion (Tudor 2018; Robertson 2019), without offering insight into the authentic identities of migrants.

\section{Conclusion}

The recent developments of discursive approaches captured in this review suggest that moving beyond traditional positivist social science epistemologies with Western rule of law assumptions opens new analytical space for understanding the complicated position of migrants in societies. Frameworks are in continual need of revisiting, however, thus demonstrating the beauty and danger of critical perspectives for the social scientific process: while critical theories can breathe new life and perspective into concepts entrenched in power imbalances, they can themselves become hegemonic discourses. Securitization studies is a case in point of a framework that started as a critical scholarship but is now under fire for its (and even its critics) entrenchment in racial power dynamics (Hansen 2020), and the question of whether these critiques can or will serve to refine existing scholarship or chart a new course forward remains open (Wæver and Buzan 2020). In relation to migrant othering, I have explored in this article how the lives of mobile people do not easily map onto legal, political, social, or even discursive categories, yet I suggest that even critical approaches can contribute to the process of othering, for example, by focusing on the state and society producing the othering (Makarychev 2018), or even on subcategories within the migrant group, such as those involved in migration brokerage. In other words, the migrant "us" does not appear in these literatures. They are rather concerned with migrants only as Other.

Considering migrants' continually disenfranchised state, it seems there should be a somewhat natural link between migrant othering and the study of national identity, which also centers on ideas of inclusion and exclusion. Yet this survey of recent literature suggests that whether or not othering contributes to a discussion of national identity depends to a large extent on the focal point of analysis. Each of the approaches to migrant othering addressed here, whether a technology of governance or a scholarly approach, has its own focal point: for populism, the people and the electoral process; for securitization, the population and its security; for biopolitics, the state and its productive population; and for critical scholarship, hegemonic discourses and the groups these disenfranchise. These focal points help to identify the mechanisms of migrant othering by the actors involved and the strategies they use. In none of these literatures is the focal point a nation or nationlike identity group, leaving any linkages between migrant othering and the nationalism literature untenable. Further, in each case the migrant Other comes up against a different frame of reference, leaving migrants themselves (or any sense of migrant identity) somewhat lost amid the analytical frameworks.

What is the utility, then, of discussing migrant othering in relation to the study of nationalism? This exercise has focused on identifying fault lines between the literatures addressing migrant othering and the concept of nationalism rather than building the bridges that are necessary to leverage accumulated wisdom across academic traditions. Nevertheless, an important outcome of assessing boundaries is that it lays bare the limits of the types of dichotomous thinking that are embedded in us-versus-them frameworks, whether in the study of nationalism, migration, race, or gender. These limits become clear even when migrant othering is rejected out of humanitarian impulse but migrants are recast as victims of circumstance, structure, policy, or exploitative forces, effectively re-othered vis-à-vis those with agency. Analytically, the category of Other is only 
potentially useful in juxtaposition to a category of something. Consequently, there is a danger of analytical imprecision if the Other becomes simply a residual category for all of the things that the focal point of analysis is not. The concept of the migrant Other suffers from exactly this lack of precision that comes with dichotomous thinking. Migrants, being an almost infinitely diverse category of mobile people, can be cast against myriad points of comparison. Without careful attention to frames and labels, analysis may quickly become a slippery slope of othering and re-othering that has normative implications for those excluded and in continual need of reenfranchisement.

Acknowledgements. The author thanks Irina Kuznetsova and Agnieszka Kubal for many conversations that sparked ideas elaborated in this article.

Disclosures. Author has nothing to disclose.

Financial Support. This research was supported by a Tomsk State University Competitiveness Improvement Programme grant.

\section{Notes}

1 In this sense, migration-related populism can also appear on the left, from those criticizing the political establishment's exclusion of migrants (Arcarazo and Freier 2015).

2 In some sense, the biopolitics literature is most like the traditional migration politics literature, which focuses on state policies and the rights these policies afford (or do not afford) migrants. The liberal paradox (Hollifield 2004) captures the idea that liberal (sometimes humanitarian) norms and policies advocated by democratic populations increasingly diverge. Though these literatures share a focus on legal mechanisms, the migration politics literature does not tend toward biopolitical framings, which are more common in anthropological approaches.

3 Not unlike securitization's so-called extraordinary means.

4 A subset of the biopolitics literature refers to this control over death as necropolitics or thanatopolitics (Wright 2011; Round and Kuznetsova 2016; Squire 2017; Bird and Short 2017).

5 Other veins in the migration literature take a different trajectory to address issues of structural injustice, linking migration to the concept of precarity that comes from the literature on labor and class structures.

6 Scholars may frame their research in terms of critical realism (Iosifides 2017), Orientalism (Amin-Khan 2012), methodological nationalism (Çağlar 2016; Xiang 2016), militant (or activist) research (Garelli and Tazzioli 2013; De Genova 2013), localization (Kluczewska 2019), intersectional approaches (Grosfoguel, Oso, and Christou 2015), or postcolonial/ decolonial analysis, namely, the idea that discourses have become hegemonic and must be decolonized in order to correct power imbalances (Adamson 2020).

7 These entrepreneurs are variously labeled (for example an employment agency versus a trafficker) often depending on assumptions of whether or not their activities are producing regular, legal, documented, and safe migrants and migration experiences.

\section{References}

Achilli, Luigi, and Mjriam Abu Samra. 2019. "Beyond Legality and Illegality: Palestinian Informal Networks and the EthnoPolitical Facilitation of Irregular Migration from Syria." Journal of Ethnic and Migration Studies. Published online ahead of print September 30, 2019.

Adamson, Fiona B. 2020. “Pushing the Boundaries: Can We 'Decolonize' Security Studies?” Journal of Global Security Studies 5 (1): 129-135.

Agamben, Giorgio. 1998. Homo Sacer: Sovereign Power and Bare Life. Stanford, CA: Stanford University Press.

Åkesson, Lisa, and Jill Maybritt Alpes. 2019. "What Is a Legitimate Mobility Manager? Juxtaposing Migration Brokers with the EU.” Journal of Ethnic and Migration Studies 45 (14): 2689-2705. 
Alpes, Maybritt Jill. 2013. "Migration Brokerage, Illegality, and the State in Anglophone Cameroon.” DIIS Working Paper, No. 2013:07. Copenhagen: Danish Institute for International Studies (DIIS).

Amin-Khan, Tariq. 2012. "New Orientalism, Securitisation and the Western Media's Incendiary Racism." Third World Quarterly 33 (9): 1595-1610.

Arcarazo, Diego Acosta, and Luisa Feline Freier. 2015. "Turning the Immigration Policy Paradox Upside Down? Populist Liberalism and Discursive Gaps in South America." International Migration Review 49 (3): 659-696.

Arifianto, Alexander R. 2009. "The Securitization of Transnational Labor Migration: The Case of Malaysia and Indonesia." Asian Politics \& Policy 1 (4): 613-630.

Baas, Michiel. 2017. “The Mobile Middle: Indian Skilled Migrants in Singapore and the 'Middling' Space between Migration Categories.” Transitions: Journal of Transient Migration 1 (1): 47-63.

Baird, Theodore, and Ilse Van Liempt. 2015. "Scrutinising the Double Disadvantage: Knowledge Production in the Messy Field of Migrant Smuggling." Journal of Ethnic and Migration Studies 42 (3): 1-18.

Bakewell, Oliver. 2008. "Research beyond the Categories: The Importance of Policy Irrelevant Research into Forced Migration." Journal of Refugee Studies 21 (4): 432-453.

Balčaitè, Indrè. 2020. "Brokered (Il)legality: Co-producing the Status of Migrants from Myanmar to Thailand.” In The Migration Industry in Asia, edited by Michiel Baas, 33-58. Singapore: Palgrave Pivot.

Bashirov, Galib. 2018. "Between Strong and Weak Securitization: A Comparative Study of Russian and Turkish Approaches to Migration from Central Asia.” In Eurasia on the Move: Interdisciplinary Approaches to a Dynamic Migration Region, edited by Marlene Laruelle and Caress Schenk, 13-26. Washington D.C.: Central Asia Program.

Bejarano, Carolina Alonso, Lucia López Juárez, Mirian A. Mijangos García, and Daniel M. Goldstein. 2019. Decolonizing Ethnography: Undocumented Immigrants and New Directions in Social Science. Durham, NC: Duke University Press.

Bertrand, Sarah. 2018. "Can the Subaltern Securitize? Postcolonial Perspectives on Securitization Theory and Its Critics." European Journal of International Security 3 (3): 281-299.

Bigo, Didier. 2014. “The (In)securitization Practices of the Three Universes of EU Border Control: Military/Navy-Border Guards/Police-Database Analysts." Security Dialogue 45 (3): 209-225.

Bigo, Didier, and Emma McCluskey. 2018. "What Is a PARIS Approach to (In)securitization? Political Anthropological Research for International Sociology." In The Oxford Handbook of International Security, edited by Alexandra Gheciu and William C. Wohlforth, 116-130. Oxford: Oxford University Press.

Billiet, Jaak, Bart Meuleman, and Hans De Witte. 2014. "The Relationship between Ethnic Threat and Economic Insecurity in Times of Economic Crisis: Analysis of European Social Survey Data." Migration Studies 2 (2): 135-161.

Bird, Greg, and Jon Short. 2017. "Cultural and Biological Immunization: A Biopolitical Analysis of Immigration Apparatuses." Configurations 25 (3): 301-326.

Bos, Linda, and Kees Brants. 2014. "Populist Rhetoric in Politics and Media: A Longitudinal Study of the Netherlands." European Journal of Communication 29 (6): 703-719.

Buzan, Barry, and Ole Waever. 2003. Regions and Powers: The Structure of International Security. Cambridge: Cambridge University Press.

Bylander, Maryann. 2019. “Is Regular Migration Safer Migration? Insights from Thailand.” Journal on Migration and Human Security 7 (1): 1-18.

Çağlar, Ayse. 2016. "Still 'Migrants' After All Those Years: Foundational Mobilities, Temporal Frames and Emplacement of Migrants." Journal of Ethnic and Migration Studies 42 (6): 952-969.

Casas-Cortes, Maribel, Sebastian Cobarrubias, and John Pickles. 2015. "Riding Routes and Itinerant Borders: Autonomy of Migration and Border Eternalization.” Antipode 47 (4): 894-914.

Collyer, Michael, and Hein De Haas. 2012. “Developing Dynamic Categorisations of Transit Migration.” Population, Space and Place 18 (4): 468-481.

Crawley, Heaven, and Dimitris Skleparis. 2018. "Refugees, Migrants, Neither, Both: Categorical Fetishism and the Politics of Bounding in Europe's 'Migration Crisis," Journal of Ethnic and Migration Studies 44 (1): 48-64.

Cuttitta, Paolo, and Tamara Last. 2019. Border Deaths: Causes, Dynamics and Consequences of Migration-Related Mortality. Amsterdam: Amsterdam University Press.

Dauvergne, Catherine, and Sarah Marsden. 2014. "The Ideology of Temporary Labour Migration in the Post-global Era." Citizenship Studies 18 (2): 224-242.

Davies, Thom, and Arshad Isakjee. 2015. "Geography, Migration and Abandonment in the Calais Refugee Camp." Political Geography 100 (49): 93-95.

Davies, Thom, Arshad Isakjee, and Surindar Dhesi. 2017. "Violent Inaction: The Necropolitical Experience of Refugees in Europe.” Antipode 49 (5): 1263-1284.

Davitti, Daria. 2018. "Biopolitical Borders and the State of Exception in the European Migration 'Crisis.” European Journal of International Law 29 (4): 1173-1196.

De Cleen, Benjamin, and Yannis Stavrakakis. 2017. "Distinctions and Articulations: A Discourse Theoretical Framework for the Study of Populism and Nationalism.” Javnost - The Public 24 (4): 301-319. 
De Genova, Nicholas. 2010. “The Deportation Regime: Sovereignty, Space, and the Freedom of Movement.” In The Deportation Regime: Sovereignty, Space, and the Freedom of Movement, edited by Nicholas De Genova and Nathalie Peutz, 33-65. Durham, NC: Duke University Press.

De Genova, Nicholas. 2013. “'We Are of the Connections': Migration, Methodological Nationalism, and 'Militant Research"” Postcolonial Studies 16 (3): 250-258.

De Genova, Nicholas. 2015. “The Border Spectacle of Migrant 'Victimisation.”' Open Democracy, May 20, 2015. https:// www.opendemocracy.net/en/beyond-trafficking-and-slavery/border-spectacle-of-migrant-victimisation/. (Accessed October 29, 2020.)

De Genova, Nicholas. 2019. "Detention, Deportation, and Waiting: Toward a Theory of Migrant Detainability." Gender a výzkum 20 (1): 92-104.

Deleixhe, Martin. 2019. "Biopolitical Sovereignty and Borderlands.” Journal of Borderlands Studies 34 (5): 649-664.

Deshingkar, Priya. 2019. "The Making and Unmaking of Precarious, Ideal Subjects - Migration Brokerage in the Global South.” Journal of Ethnic and Migration Studies 45 (14): 2638-2654.

Deshingkar, Priya, C. R. Abrar, Mirza Taslima Sultana, Kazi Nurmohammad Hossainul Haque, and Md Selim Reza. 2019. "Producing Ideal Bangladeshi Migrants for Precarious Construction Work in Qatar." Journal of Ethnic and Migration Studies 45 (14): 2723-2738.

Dines, Nick, Nicola Montagna, and Vincenzo Ruggiero. 2015. “Thinking Lampedusa: Border Construction, the Spectacle of Bare Life and the Productivity of Migrants." Ethnic and Racial Studies 38 (3): 430-445.

Doty, Roxanne Lynn. 2011. "Bare Life: Border-Crossing Deaths and Spaces of Moral Alibi." Environment and Planning D: Society and Space 29 (4): 599-612.

Eger, Maureen A., and Sarah Valdez. 2019. “From Radical Right to Neo-nationalist.” European Political Science 18 (3): $379-399$.

Fassin, Didier. 2011. "Policing Borders, Producing Boundaries: The Governmentality of Immigration in Dark Times.” Annual Review of Anthropology 40: 213-226.

Ferreira, Susana. 2018. "From Narratives to Perceptions in the Securitisation of the Migratory Crisis in Europe." In Critical Perspectives on Migration in the Twenty-First Century, edited by Marianne Karakoulaki Laura Southgate, and Jakob Steiner, 57-73. Bristol: E-International Relations.

Garelli, Glenda, and Martina Tazzioli. 2013. "Challenging the Discipline of Migration: Militant Research in Migration Studies, an Introduction.” Postcolonial Studies 16 (3): 245-249.

Gilmartin, Mary, and Anna-Kaisa Kuusisto-Arponen. 2019. “Borders and Bodies: Siting Critical Geographies of Migration.” In Handbook on Critical Geographies of Migration, edited by Katharyne Mitchell, Reece Jones and Jennifer L. Fluri, 18-29. Cheltenham: Edward Elgar Publishing.

Gorodzeisky, Anastasia, and Moshe Semyonov. 2020. "Perceptions and Misperceptions: Actual Size, Perceived Size and Opposition to Immigration in European Societies." Journal of Ethnic and Migration Studies 46 (3): 612-630.

Gray, Harriet, and Anja K. Franck. 2019. "Refugees as/at Risk: The Gendered and Racialized Underpinnings of Securitization in British Media Narratives.” Security Dialogue 50 (3): 275-291.

Grosfoguel, Ramon, Laura Oso, and Anastasia Christou. 2015. “'Racism,' Intersectionality and Migration Studies: Framing Some Theoretical Reflections." Identities 22 (6): 635-652.

Hammerstad, Anne. 2014. "The Securitization of Forced Migration." In The Oxford Handbook of Refugee and Forced Migration Studies, edited by Elena Fiddian-Qasmiyeh, Gil Loescher, Katy Long, and Nando Sigona, 266-277. Oxford: Oxford University Press.

Hansen, Lene. 2020. “Are 'Core’ Feminist Critiques of Securitization Theory Racist? A Reply to Alison Howell and Melanie Richter-Montpetit.” Security Dialogue 51 (4): 378-385.

Hintjens, Helen. 2019. "Failed Securitisation Moves during the 2015 'Migration Crisis." International Migration 57 (4): 181-196.

Hollifield, James F. 2004. “The Emerging Migration State.” International Migration Review 38 (3): 885-912.

Howell, Alison, and Melanie Richter-Montpetit. 2020. "Is Securitization Theory Racist? Civilizationism, Methodological Whiteness, and Antiblack Thought in the Copenhagen School." Security Dialogue 51 (1): 3-22.

Iosifides, Theodoros. 2017. “Against 'Migration': Using Critical Realism as a Framework for Conducting Mixed-Method, Migrantization Research.” Journal of Critical Realism 16 (2): 128-142.

Jones, Reece, and Corey Johnson. 2016. "Border Militarisation and the Re-articulation of Sovereignty." Transactions of the Institute of British Geographers 41 (2): 187-200.

Kim, Jaeeun. 2018. “Migration-Facilitating Capital: A Bourdieusian Theory of International Migration.” Sociological Theory 36 (3): $262-288$.

Kluczewska, Karolina. 2019. "When IOM Encounters the Field: Localising the Migration and Development Paradigm in Tajikistan.” Journal of Ethnic and Migration Studies. Published online ahead of print November 20, 2019.

Krzyżanowski, Michał, and Per Ledin. 2017. "Uncivility on the Web: Populism in/and the Borderline Discourses of Exclusion." Journal of Language and Politics 16 (4): 566-581. 
Kuntz, Anabel, Eldad Davidov, and Moshe Semyonov. 2017. "The Dynamic Relations between Economic Conditions and Antiimmigrant Sentiment: A Natural Experiment in Times of the European Economic Crisis." International Journal of Comparative Sociology 58 (5): 392-415.

Kunz, Sarah. 2020. "Expatriate, Migrant? The Social Life of Migration Categories and the Polyvalent Mobility of Race." Journal of Ethnic and Migration Studies 46 (11): 2145-2162.

Kynsilehto, Anitta. 2017. “Mobilities, Politics, and Solidarities.” Peace Review 29 (1): 48-54.

Landry, Rachel. 2016. “The 'Humanitarian Smuggling' of Refugees: Criminal Offence or Moral Obligation.” Working Paper Series No. 119. Oxford: Refugee Studies Centre, University of Oxford.

Ma, Xinrong. 2018. “Entrapment by Consent: The Co-ethnic Brokerage System of Ethnic Yi Labour Migrants in China." PhD diss. Leiden University.

Mainwaring, Cetta, and Stephanie J. Silverman. 2017. “Detention-as-Spectacle.” International Political Sociology 11 (1): 21-38.

Makarychev, Andrey. 2018. "Bordering and Identity-Making in Europe after the 2015 Refugee Crisis." Geopolitics 23 (4): 747-753.

Matthes, Jörg, and Desirée Schmuck. 2017. “The Effects of Anti-immigrant Right-Wing Populist Ads on Implicit and Explicit Attitudes: A Moderated Mediation Model.” Communication Research 44 (4): 556-581.

Mavelli, Luca. 2017. "Governing Populations through the Humanitarian Government of Refugees: Biopolitical Care and Racism in the European Refugee Crisis.” Review of International Studies 43 (5): 809-832.

Mignolo, Walter. 2011. The Darker Side of Western Modernity: Global Futures, Decolonial Options. Durham, NC: Duke University Press.

Moffitt, Benjamin. 2015. "How to Perform Crisis: A Model for Understanding the Key Role of Crisis in Contemporary Populism." Government and Opposition 50 (2): 189-217.

Moffitt, Benjamin. 2016. The Global Rise of Populism: Performance, Political Style, and Representation. Stanford, CA: Stanford University Press.

Moncrieffe, Joy. 2007. “Introduction: Labelling, Power and Accountability; How and Why 'Our' Categories Matter.” In The Power of Labelling, edited by Joy Moncrieffe and Rosalind Eyben, 1-16. London: Earthscan.

Moret, Joëlle, Apostolos Andrikopoulos, and Janine Dahinden. 2019. "Contesting Categories: Cross-Border Marriages from the Perspectives of the State, Spouses and Researchers." Journal of Ethnic and Migration Studies. Published online ahead of print July 17, 2019.

Muis, Jasper, and Tim Immerzeel. 2017. "Causes and Consequences of the Rise of Populist Radical Right Parties and Movements in Europe." Current Sociology 65 (6): 909-930.

Picherit, David. 2019. "Labour Migration Brokerage and Dalit Politics in Andhra Pradesh: A Dalit Fabric of Labour Circulation." Journal of Ethnic and Migration Studies 45 (14): 2706-2722.

Robertson, Shanthi. 2019. “Status-Making: Rethinking Migrant Categorization.” Journal of Sociology 55 (2): 219-233.

Round, John, and Irina Kuznetsova. 2016. "Necropolitics and the Migrant as a Political Subject of Disgust: The Precarious Everyday of Russia’s Labour Migrants." Critical Sociology 42 (7/8): 1017-1034.

Rydgren, Jens. 2007. “The Sociology of the Radical Right.” Annual Review of Sociology 33:241-262.

Rygiel, Kim. 2011. "Bordering Solidarities: Migrant Activism and the Politics of Movement and Camps at Calais." Citizenship Studies 15 (1): 1-19.

Rygiel, Kim. 2016. "Dying to Live: Migrant Deaths and Citizenship Politics along European Borders: Transgressions, Disruptions, and Mobilizations." Citizenship Studies 20 (5): 545-560.

Sajjad, Tazreena. 2018. "What's in a Name? 'Refugees,' 'Migrants' and the Politics of Labelling." Race \& Class 60 (2): $40-62$.

Sakki, Inari, and Katarina Pettersson. 2016. "Discursive Constructions of Otherness in Populist Radical Right Political Blogs." European Journal of Social Psychology 46 (2): 156-170.

Salgado, Susana. 2019. -Where's Populism? Online Media and the Diffusion of Populist Discourses and Styles in Portugal.” European Political Science 18 (1): 53-65.

Sampson, Robyn. 2019. “The Biopolitics of Alternatives to Immigration Detention.” In Handbook on Critical Geographies of Migration, edited by Reece Jones, Jennifer L. Fluri, and Katharyne Mitchell, 255-266. Northampton, MA: Edward Elgar Publishing.

Schenk, Caress. 2018. “Anti-migrant, but Not Nationalist: Pursuing Statist Legitimacy through Immigration Discourse and Policy.” In Russia before and after Crimea: Nationalism and Identity, 2010-2017, edited by Pål Kolstø and Helge Blakkisrud, 236-257. Edinburgh: Edinburgh University Press.

Schmitt, Carl. 2005. Political Theology: Four Chapters on the Concept of Sovereignty. Chicago, IL: University of Chicago Press. Smith, Kate, and Louise Waite. 2019. "New and Enduring Narratives of Vulnerability: Rethinking Stories about the Figure of the Refugee." Journal of Ethnic and Migration Studies 45 (13): 2289-2307.

Squire, Vicki. 2017. "Governing Migration through Death in Europe and the US: Identification, Burial and the Crisis of Modern Humanism.” European Journal of International Relations 23 (3): 513-532.

Stachowitsch, Saskia, and Julia Sachseder. 2019. "The Gendered and Racialized Politics of Risk Analysis: The Case of Frontex." Critical Studies on Security 7 (2): 107-123.

Stavrakakis, Yannis, Giorgos Katsambekis, Alexandros Kioupkiolis, Nikos Nikisianis, and Thomas Siomos. 2018. "Populism, Anti-populism and Crisis." Contemporary Political Theory 17 (1): 4-27. 
Stockemer, Daniel, Arne Niemann, Doris Unger, and Johanna Speyer. 2020. “The 'Refugee Crisis,' Immigration Attitudes, and Euroscepticism." International Migration Review 54 (3): 883-912.

Stroschein, Sherrill. 2019. "Populism, Nationalism, and Party Politics." Nationalities Papers 47 (6): 923-935.

Talleraas, Cathrine. 2020. "Who Are the Transnationals? Institutional Categories beyond 'Migrants.” Ethnic and Racial Studies 43 (4): 652-671.

Tazzioli, Martina, and William Walters. 2016. “The Sight of Migration: Governmentality, Visibility and Europe's Contested Borders." Global Society 30 (3): 445-464.

Tuckett, Anna. 2018. "Ethical Brokerage and Self-fashioning in Italian Immigration Bureaucracy." Critique of Anthropology 38 (3): 245-264.

Tudor, Alyosxa. 2018. "Cross-Fadings of Racialisation and Migratisation: The Postcolonial Turn in Western European Gender and Migration Studies.” Gender, Place \& Culture 25 (7): 1057-1072.

Van Reekum, Rogier. 2016. “The Mediterranean: Migration Corridor, Border Spectacle, Ethical Landscape.” Mediterranean Politics 21 (2): 336-341.

Van Reekum, Rogier, and Willem Schinkel. 2017. "Drawing Lines, Enacting Migration: Visual Prostheses of Bordering Europe." Public culture 29 (1): 27-51.

Wæver, Ole, and Barry Buzan. 2020. "Racism and Responsibility-The Critical Limits of Deepfake Methodology in Security Studies: ARreply to Howell and Richter-Montpetit." Security Dialogue 51 (4): 386-394.

Walters, William. 2015. "Reflections on Migration and Governmentality." Movements. Journal for Critical Migration and Border Regime Studies 1 (1): 1-25.

Watson, Scott D. 2009. The Securitization of Humanitarian Migration: Digging Moats and Sinking Boats. New York: Routledge.

Wee, Kellynn, Charmian Goh, and Brenda S. A. Yeoh. 2019. "Chutes-and-Ladders: The Migration Industry, Conditionality, and the Production of Precarity among Migrant Domestic Workers in Singapore." Journal of Ethnic and Migration Studies 45 (24): 2672-2688.

Wiggen, Mette. 2012. "Rethinking Anti-immigration Rhetoric after the Oslo and Utøya Terror Attacks." New Political Science 34 (4): 585-604.

Wodak, Ruth. 2015. The Politics of Fear: What Right-Wing Populist Discourses Mean. Los Angeles: Sage.

Wodak, Ruth, and Michał Krzyżanowski. 2017. “Right-Wing Populism in Europe \& USA.” Journal of Language and Politics 16 (4): 471-484.

Wright, Melissa W. 2011. "Necropolitics, Narcopolitics, and Femicide: Gendered Violence on the Mexico-US Border." Signs: Journal of Women in Culture and Society 36 (3): 707-731.

Xiang, Biao. 2016. "Beyond Methodological Nationalism and Epistemological Behaviouralism: Drawing Illustrations from Migrations within and from China." Population, Space and Place 22 (7): 669-680.

Yuval-Davis, Nira, Georgie Wemyss, and Kathryn Cassidy. 2018. "Everyday Bordering, Belonging and the Reorientation of British Immigration Legislation.” Sociology 52 (2): 228-244.

Zvobgo, Kelebogile, and Meredith Loken. 2020. “Why Race Matters in International Relations.” Foreign Policy, June 19, 2020. https://foreignpolicy.com/2020/06/19/why-race-matters-international-relations-ir/. (Accessed November 6, 2020.)

Cite this article: Schenk, C. 2021. The Migrant Other: Exclusion without Nationalism?. Nationalities Papers 49: 397-408, doi:10.1017/nps.2020.82 